\title{
Working
}

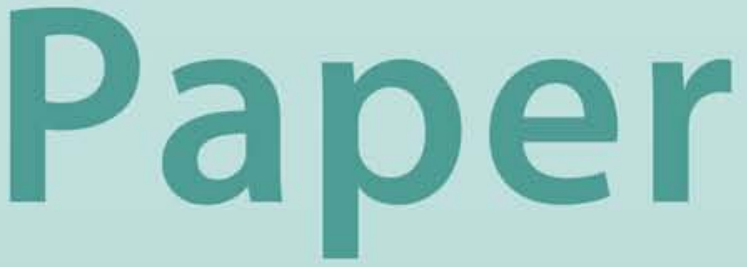




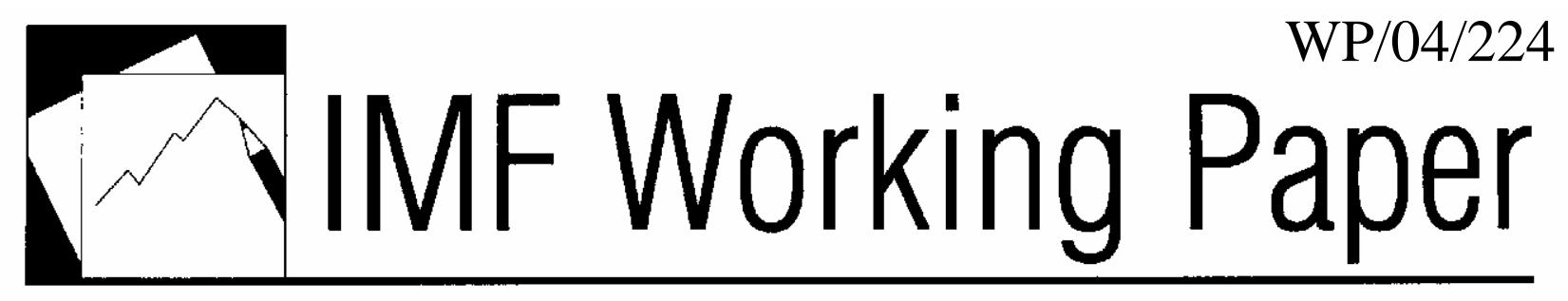

\section{Macroeconomic Implications of Natural Disasters in the Caribbean}

Tobias N. Rasmussen 


\title{
IMF Working Paper
}

Western Hemisphere Department

\section{Macroeconomic Implications of Natural Disasters in the Caribbean}

\author{
Prepared by Tobias N. Rasmussen ${ }^{1}$ \\ Authorized for distribution by David O. Robinson
}

December 2004

\begin{abstract}
This Working Paper should not be reported as representing the views of the IMF. The views expressed in this Working Paper are those of the author(s) and do not necessarily represent those of the IMF or IMF policy. Working Papers describe research in progress by the author(s) and are published to elicit comments and to further debate.

Each year natural disasters affect about 200 million people and cause about $\$ 50$ billion in damage. This paper compares the incidence of natural disasters across countries along several dimensions and finds that the relative costs tend to be far higher in developing countries than in advanced economies. The analysis shows that small island states are especially vulnerable, with the countries of the Eastern Caribbean standing out as among the most disaster-prone in the world. Natural disasters are found to have had a discernible macroeconomic impact, including large effects on fiscal and external balances, pointing to an important role for precautionary measures.

JEL Classification Numbers: G22, H30, O10, Q54
\end{abstract}

Keywords: Natural Disasters, Eastern Caribbean, Developing Countries

Author(s) E-Mail Address: trasmussen@imf.org

\footnotetext{
${ }^{1}$ Tobias N. Rasmussen is an economist in the IMF's Western Hemisphere Department. The author thanks Paul Cashin, Prachi Mishra, David O. Robinson, Ratna Sahay, and seminar participants at the IMF and at the Ministries of Finance of Antigua and Barbuda, Grenada, Dominica, St. Lucia, St. Kitts and Nevis, and St. Vincent and the Grenadines for their many useful comments and suggestions.
} 
I. Introduction

II. The Incidence of Natural Disasters

III. The Macroeconomic Implications of Natural Disasters .............................................. $\underline{8}$

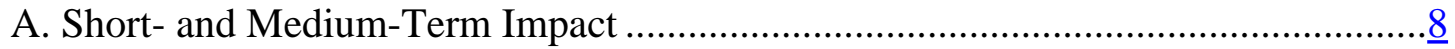

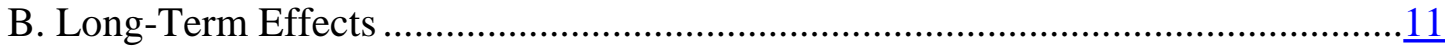

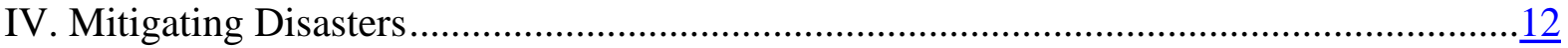

A. Coping With Risk: The Role of Insurance and Capital Markets ...........................12

B. Domestic Public Policy to Reduce Risk and Lessen the Impact...........................14

C. International Assistance and Cooperation .....................................................

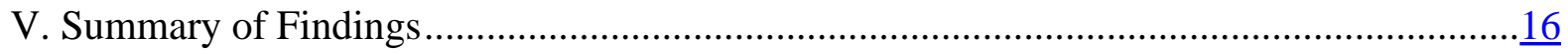

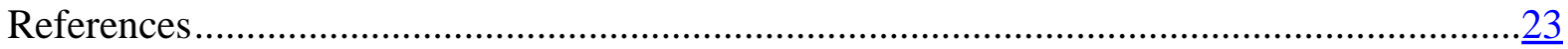

Tables

Table 1. Frequency and Impact of Natural Disasters, 1970-2002 ...............................17

Table 2. Determinants of Vulnerability to Natural Disaster, 1970-2002 .......................18

Table 3. Natural Disasters in ECCU Countries, 1970-2002 .......................................19

Table 4. Worldwide Incidence of Natural Disasters, 1970-2002 .................................20

Table 5. Correlations Between Measures of Proneness to Natural Disasters and Selected Macroeconomic Variables, 1970-2002 ..........................................21

Table 6. Volatility in Income and Consumption, 1970-2002 ........................................22

Figures

Figure 1. Global Frequency and Impact of Natural Disasters, 1970-2002 ….................

Figure 2. Cross-Country Frequency and Impact of Natural Disasters, 1970-2002 ........... $\underline{6}$

Figure 3. Median Impact of 12 Large Natural Disasters in the ECCU, 1970-2002 .........10

\section{Boxes}

Box 1. Review of Literature on Macroeconomic Implications of Natural Disasters.......... $\underline{9}$

Box 2. New Instruments for Dealing with Natural Hazard Risk 


\section{INTRODUCTION}

Wind storms, floods, droughts, and other potentially damaging natural events occur regularly across the world, but only on occasion do they lead to natural disasters. Whether an event will develop into a natural disaster will depend on its physical force, its location, the vulnerability of population and infrastructure, the level of preparedness, and a host of other factors. While such events cannot be eliminated, much can be done to prevent natural disasters. Emphasizing the implications for the Eastern Caribbean, this paper seeks to identify determinants of vulnerability to natural disaster, the economic impact, and possible remedies.

The central source of data used in the analysis is the EM-DAT database compiled by the Centre for Research on the Epidemiology of Disasters (CRED, 2004), the most comprehensive database on natural disasters that is publicly available. Natural disasters are here defined as events due to natural causes that led to 10 or more fatalities, affected 100 or more people, or resulted in a call for international assistance or the declaration of a state of emergency. The database contains information on 14,535 natural disasters since 1900, including estimates of the number of people affected and the value of damage. ${ }^{2}$ According to these data, since 1970 natural disasters have affected more than 5 billion people and have caused more than $\$ 1$ trillion in damage.

The main contribution of this paper is to provide a comprehensive cross-country comparison of the incidence of natural disasters. To this end, countries are compared along four dimensions: the number of events divided by land area; the number of events divided by population; the number of affected persons divided by total population; and damage divided by GDP. Each of these measures has been used individually in previous studies, but bringing them together provides a broader understanding of countries' vulnerabilities.

The results show that developing countries tend to suffer most from natural disasters, especially in terms of the number of persons affected and the value of the damage. Small island states are found to have an especially high frequency of natural disasters, with the countries of the Eastern Caribbean Currency Union (ECCU) standing out owing to the large number of hurricanes. ${ }^{3}$ Based on the experience since 1970, a natural disaster inflicting damage equivalent to more than 2 percent of the affected country's GDP can be expected to

\footnotetext{
2 EM-DAT defines as affected people requiring immediate assistance during a period of emergency. The figures for damage capture the value of direct damage to infrastructure, crops, housing, and other capital. The figures are based on a large number of different primary sources and are associated with substantial uncertainty, especially the estimates of damage where different agencies often report widely different numbers. Despite the wealth of information, the data still suffer from under-reporting, especially in the earlier periods, and the analysis therefore focuses on the period since 1970 .

${ }^{3}$ The ECCU countries are Anguilla, Antigua and Barbuda, Dominica, Grenada, Montserrat, St. Kitts and Nevis, St. Lucia, and St. Vincent and the Grenadines. Anguilla and Montserrat are British dependencies and are not analyzed independently.
} 
hit the ECCU roughly once every two and a half years. The very high exposure to natural hazards in the Eastern Caribbean has recently been exemplified in Grenada, which suffered devastating damage from Hurricane Ivan in September 2004.

Vulnerability to natural disasters is found to have important policy implications. Managing natural disaster risk would ideally involve use of market insurance mechanisms. However, the market for natural disaster insurance is not well developed and is largely absent in many developing countries. As an alternative, countries can self-insure by generating public savings in good times to cover potential increases in expenditure necessitated by future natural disasters. More appropriate building practices and other preventive measures may also substantially lessen a country’s exposure to natural hazards.

The remainder of this chapter is organized as follows. Section II presents an overview of the incidence of natural disasters. Section III discusses the macroeconomic implications. Section IV offers an outline of different strategies to mitigate the impact of natural disasters. Section $\mathrm{V}$ summarizes the key findings.

\section{THE INCIDENCE OF NATURAL DisASTERS}

Natural disasters are becoming much more common (Figure 1). Three times as many disasters were recorded in the 1990 s as in the 1970s, with broadly similar increases seen in the estimates of the number of persons affected and the cost of damage. While part of the observed increase may reflect more comprehensive reporting, it is widely believed that there are two fundamental reasons for these developments. First, an increased concentration of population in high-risk areas (see Freeman et al., 2003). Second, an increase in the frequency and intensity of extreme weather events. This second development is generally thought to be associated with the rise in mean global surface temperatures and is expected to become more pronounced during the twenty-first century (Intergovernmental Panel on Climate Change, 2001).
Figure 1. Global Frequency and Impact of Natural Disasters, 1970-2002

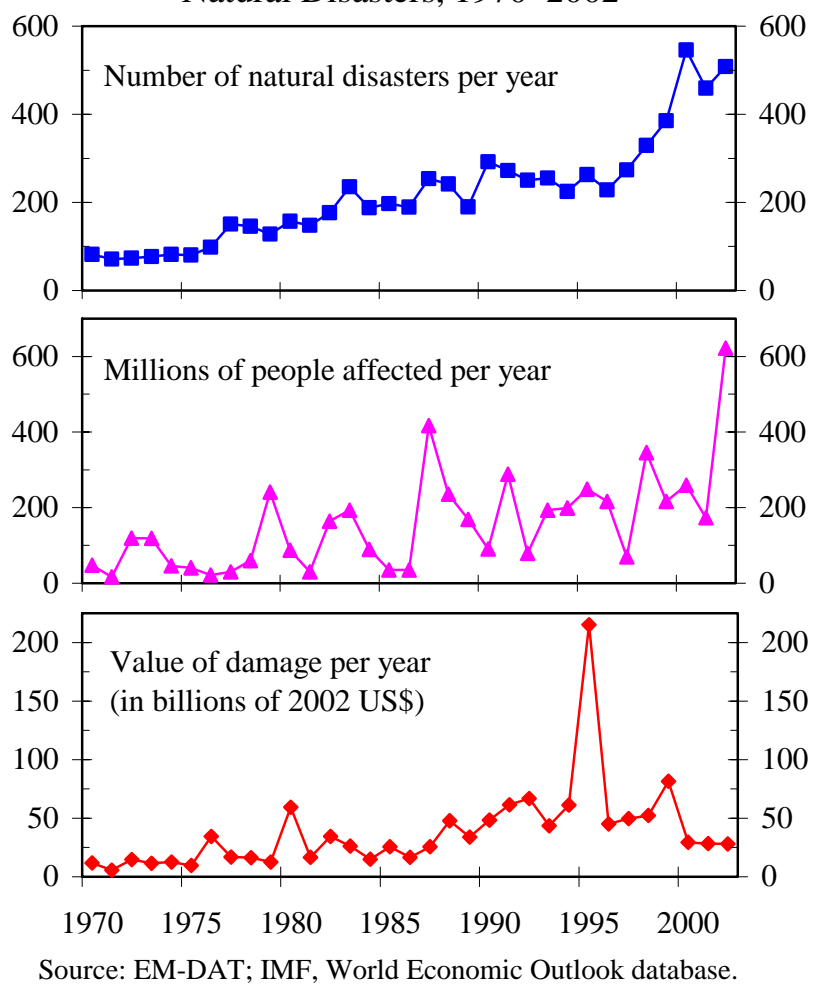

Of the more than 6,000 natural disasters recorded during 1970-2002, three-fourths of the events and 99 percent of the people affected were in developing countries (Table 1). In developing countries natural disasters have, on average, affected over 2 percent of the population each year and caused more than one half of 1 percent of GDP in damage. Both these figures are about 10 times greater than in advanced economies. This observation is 
consistent with other studies of the implications of natural disasters, which tend to find that, both across and within countries, the poor are usually the primary victims, as they tend to live in high-risk areas, rely on fragile infrastructure, and have jobs that depend on the weather (Freeman et. al, 2003; IMF, 2003; and World Bank, 2003).

In order to assess the frequency of events - in contrast to their costs, as reflected by the estimates of damage and the number of affected persons - it is useful to consider the number of natural disasters in relation to country size. Comparing the number of events to land area and population shows that small island states tend to have the highest frequency of natural disasters (Figure 2). This result is presumably explained by the fact that many small island states are located in areas prone to tropical cyclones to which they are especially vulnerable owing to their relatively long coast lines. In many cases, the high frequency of natural disasters in small island states appears to translate into relatively high levels of damage. However, the number of affected persons is not particularly high in most of these countries. This may well reflect that most small island states have substantially higher income levels than the developing country average.

Cross-country regression analysis points to a clear negative relationship between income and the number of persons affected by natural disasters, suggesting that the capacity of countries to avoid the human cost of disasters improves as income levels increases. Regressing the percentage of population affected on the number of natural disasters divided by population and on per capita income produces highly significant coefficients with the expected signs (Table 2). When adding additional explanatory variables, there are some signs of higher quality of governance being associated with a larger percentage of the population being affected, perhaps because countries scoring poorly on this measure tend to underreport the human costs.

In contrast to the percentage of population affected, the relative magnitude of damage does not appear to depend on the level of income. When considering the value of damage divided by GDP as the dependent variable in the regressions, only the frequency of events per capita shows a consistently significant coefficient. Economic development in itself does thus not appear to imply that individual events become less costly in economic terms. Also, while drawing firm conclusions is complicated by the fact that the variables are correlated, neither the share of agriculture in GDP nor the investment-to-GDP ratio (a proxy for the size of the capital stock potentially subject to damage) appears to have a significant impact on the number of affected persons or the value of damage, as one might have expected. In all cases, the measure of frequency based on dividing the number of events by population is associated with a more significant coefficient than the one based on dividing by land area. 
Figure 2. Cross-Country Frequency and Impact of Natural Disasters, 1970-2002
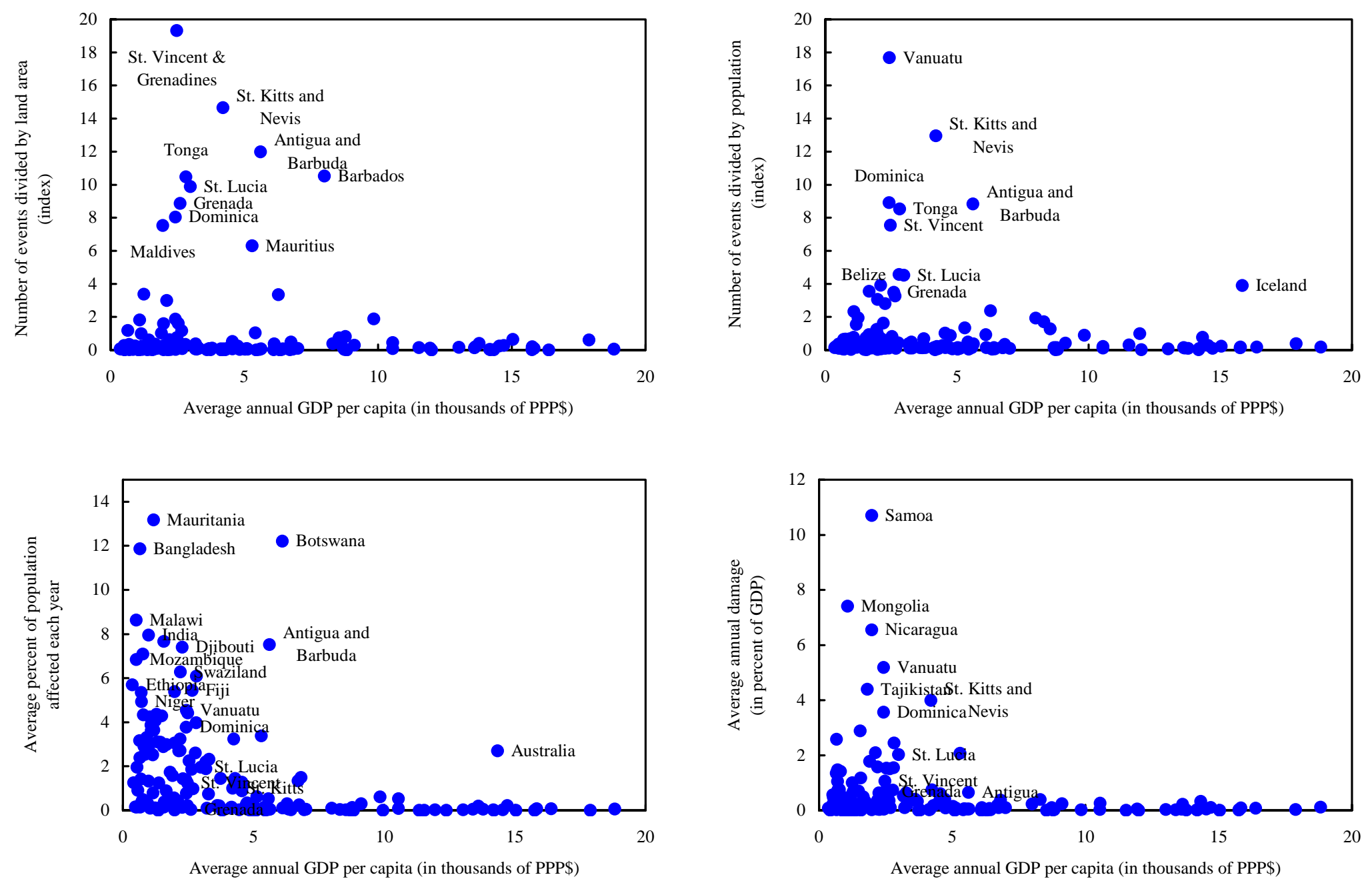

Source: EM-DAT; IMF, World Economic Outlook database; World Bank, World Development Indicators. 
The Eastern Caribbean is in the Atlantic hurricane belt, and several of the countries are also subject to potential volcanic eruptions. Typically occurring during the June-November period, wind storms have caused 34 of the 44 natural disasters recorded since 1970 in the six ECCU countries that are Fund members (Table 3). On average, a natural disaster occurred once every four and a half years in each of the six countries. Considering only incidents that affected at least 2 percent of a country's population or inflicted damage of at least 2 percent of GDP, EM-DAT figures point to such events occurring in the individual countries once every nine years or somewhere in the region once every two and a half years. Among these large disasters, the median number of affected persons amounted to 9 percent of the country's population and the median value of damage was equivalent to 14 percent of the country's annual GDP.

Some events have been truly devastating, affecting the population of an entire country and causing damage exceeding 100 percent of annual GDP. For example, in 1979 Hurricane David hit Dominica with winds in excess of 130mph, killing 42 people, damaging 95 percent and completely destroying 12 percent of buildings, damaging or destroying the entire banana crop and 75 percent of the country's forests, rendering virtually the entire population homeless, and leading to the temporary exodus of about a quarter of the population (Benson et al., 2001). Consequently, GDP plummeted by 17 percent, central government current expenditure increased by 31 percent with capital expenditure increasing even more rapidly, and the fiscal deficit increased from 3.1 percent of GDP in 1978 to 8.1 percent in 1981 despite a sizable increase in foreign grant receipts.

By several measures, the ECCU countries are among the most disaster prone in the world (Table 4). ${ }^{4}$ When comparing the number of natural disasters during 1970-2002 to land area, all six ECCU countries rank among the 10 most disaster prone in the world. By this measure, they were more than 12 times as exposed as the average country. The incidence is only slightly lower when one compares the number of disasters to population. Interestingly, the results do not reveal clear differences between the ECCU countries. Given that the northern islands (Antigua and Barbuda, St. Kitts and Nevis, and Dominica) are closer to the center of the hurricane belt than the southern islands (St. Lucia, St. Vincent and the Grenadines, and Grenada), one would have expected the former countries to rank higher in terms of vulnerability to natural disaster, but that is not consistently the case.

The costs of natural disasters in the ECCU appear somewhat lower than the very high frequency of events would suggest. The average cumulative damage was equivalent to 66 percent of annual GDP, compared to a worldwide average of 21 percent, and only two of the six countries are in

\footnotetext{
${ }^{4}$ Crowards and Coulter (1998), ECLAC (2000), and Pollner (2001) reach a similar conclusion. At a broader level, the findings are also in line with the composite vulnerability indexes proposed by several international institutions (see Atkins et al., 2000; Crowards, 2000a; and United Nations, 2000). In addition to proneness to natural disaster, these indexes include factors such as susceptibility to terms of trade shocks and concentration of exports to rank countries according to their overall vulnerability. The different indices all find that small isolated low-income countries are the most vulnerable, with the ECCU countries in most cases ranking near the very top.
} 
the top 10 according to this measure. In terms of the human cost, only Antigua and Barbuda was among the top 10 according to the percentage of the population affected. The relatively small number of persons affected by natural disaster in the ECCU is consistent with the tendency for countries to become more resilient as they become richer. Average per capita GDP in the six ECCU countries was US\$5,500 in 2002, compared with US\$1,400 for the 20 most vulnerable countries based on the percentage of the population affected. The relatively high level of income in ECCU countries thus appears to substantially mitigate the human cost of the frequent natural disasters.

\section{THE MACROECONOMIC IMPLiCATIONS OF NATURAL DISASTERS}

In principle, one can distinguish between several sources of loss from natural disasters. There is a direct cost from loss of assets, as reflected by EM-DAT's measure of damage. In addition, disruption of economic activity may lead to loss of income. Finally, these impacts may cause spillovers at the macroeconomic level, as fiscal and external pressures can lead to imbalances that spark economic crises, and an increase in the incidence of poverty can create social unrest. It is therefore useful to examine the broader impact.

\section{A. Short- and Medium-Term Impact}

Studies of the impact of natural disasters (see Box 1) point to a discernible short-term impact. A common finding is an immediate contraction in output and a worsening of external and fiscal balances, with the impact somewhat softened by an increase in transfers from abroad. Figure 3 shows the dynamic impact of the 12 natural disasters in the ECCU since 1970 for which the damage estimate exceeded 2 percent of GDP. While the small number of observations prevents formal statistical analysis, the results suggest that the impact conformed to the general pattern, although in some cases it seems to have been more severe than seen elsewhere.

The 12 large natural disasters in the ECCU were associated with a median reduction in sameyear real GDP growth of 2.2 percentage points, as well as with a large decline in agricultural production and an offsetting increase in investment. Exports declined and imports increased, resulting in a staggering median increase in the current account deficit equal to 10.8 percent of GDP. These very large same-year effects are all the more striking when one considers that all the events occurred in the second half of the year. The impact on the central government was less clear, with a large variation in outcomes. Nevertheless, the tendency appears to have been a marked increase in expenditure and a small reduction in total revenue (including grants) despite an increase in inflows of official assistance and aid. As a result, the median public debt-to-GDP ratio increased sharply by a cumulative 6.5 percentage points over three years. 


\section{Box 1. Review of Literature on Macroeconomic Implications of Natural Disasters}

A number of studies reveal that natural disasters are typically associated with:

- $\quad$ An immediate contraction in economic output. Natural disasters are found to have been usually accompanied by a reduction in same-year GDP growth, with the impact ranging from very small to 20 percentage points or more (e.g., Dominica in 1979). Among studies looking at Latin America and the Caribbean, Auffret (2003a) considers 16 natural disasters and finds that 1 percent of GDP in direct damage reduced same-year GDP growth by 0.5 percentage point; Charvériat (2000) analyzes 35 events with a median damage of 3 percent of GDP and finds that same-year GDP growth fell in 28 cases, with an overall median reduction of 1.7 percentage points; and Crowards (2000b) finds that same-year GDP growth fell by an average of 3.1 percentage points following 21 major disasters. Evidence of an impact on growth beyond the contemporaneous drop is mixed. For example, Caselli and Malhotra (2004) present a comprehensive statistical study and conclude that disasters have no significant impact on the growth path.

- $\quad$ A worsening of external balances. Several studies have found that natural disasters typically result in an increase in imports (e.g., for reconstruction materials and to compensate for lost production) and that exports tend to suffer. For example, ECLAC (2000) considers 42 large natural disasters in Latin America and the Caribbean and finds that these were, on average, associated with a deterioration in the balance of payments by an amount equal to about one-third of the estimated damage. Crowards (2000b) finds that 21 major natural disasters led to an average worsening of the trade balance owing to an increase in import growth and, to a lesser extent, a reduction in export growth. Benson et al. (2001) find that a country's dependence on agricultural exports is an important indicator of the magnitude of the deterioration in the trade balance.

- $\quad$ A deterioration in fiscal balances. While significant relationships are difficult to establish, the literature suggests that natural disasters can put substantial pressure on public finances. Emergency assistance and reconstruction efforts call for higher government expenditure, and, at the same time, tax revenue may shrink because of the decline in economic activity. Consequently, the result is usually a worsening of public balances. For example, IMF (2003) finds that five large exogenous shocks in Africa were associated with same-year increases in fiscal deficits of up to 3 percent of GDP. However, in many cases natural disasters appear to have had very little impact on fiscal balances, perhaps because countries are constrained by existing expenditure envelopes (Benson and Clay, 2003a).

- $\quad$ An increase in poverty. Natural disasters have been found to have a disproportionate impact on the poorer segments of the population. Low-income households often settle in the most vulnerable areas and live in poorly constructed housing (World Bank, 2003). In addition, the poor have fewer assets and limited access to credit and are therefore less able to cushion the impact on consumption of disruptions to income (IMF, 2003). While natural disasters thus appear to have an adverse effect on poverty, it is unclear how quickly affected households can recover. 
Figure 3. Median Impact of 12 Large Natural Disasters in the ECCU, 1970-2002

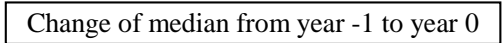

Real GDP (\% change)

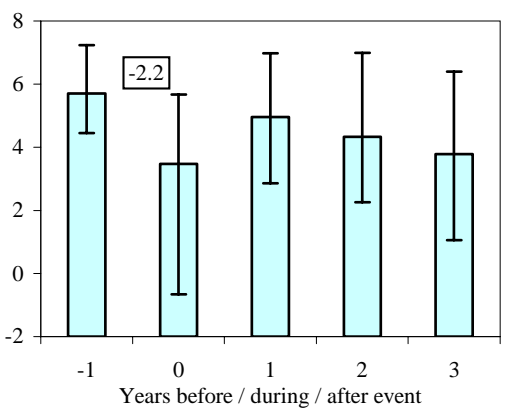

Exports (Goods \& Services, \% of GDP)

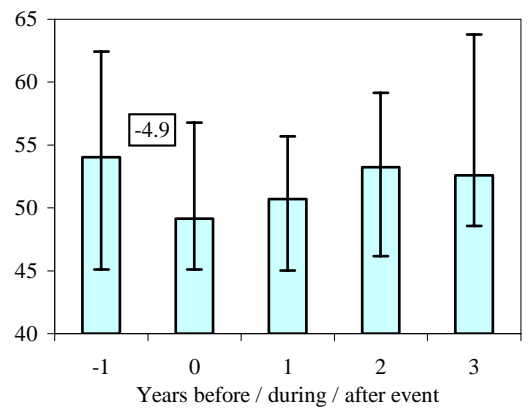

Central Gov. Revenue (\% of GDP)

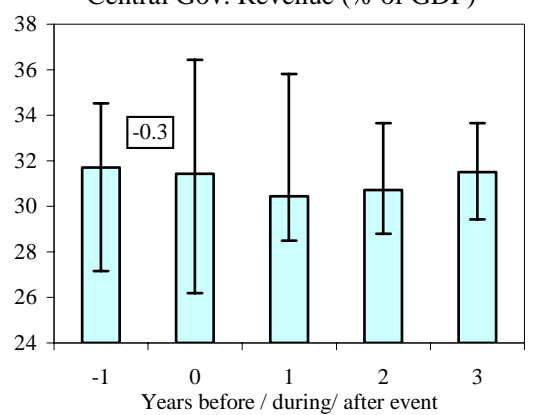

Official Assistance and Aid (\% of GDP)

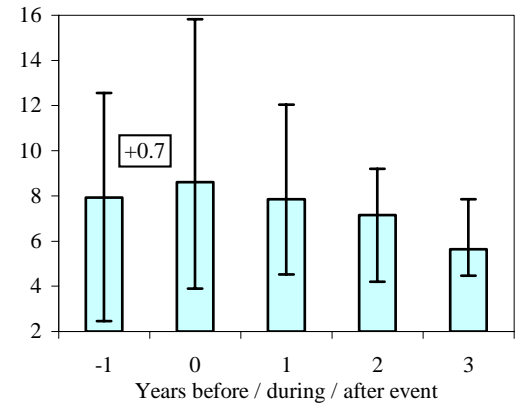

Agricultural Production (\% change) $1 /$

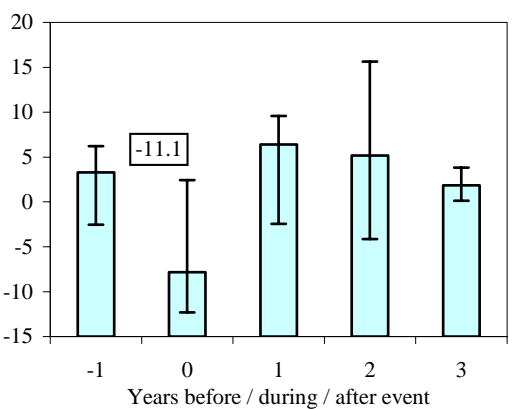

Imports (Goods \& Services, \% of GDP)

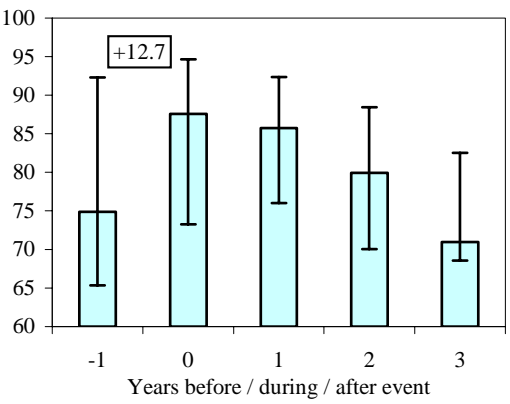

Public Consumption (\% of GDP) 2/

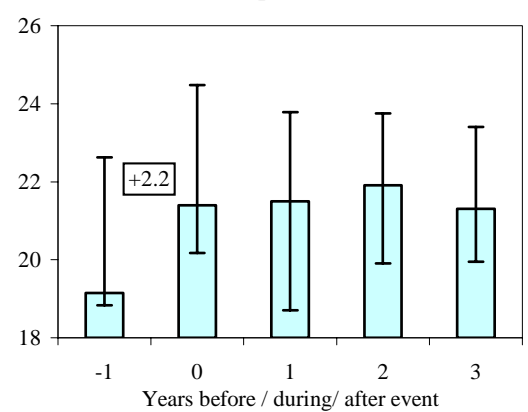

Central Gov. Deficit (\% of GDP)

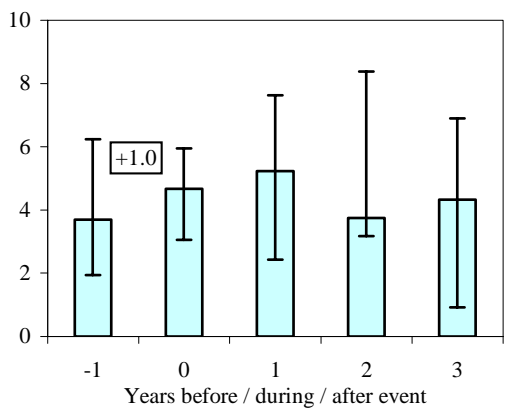

Investment (\% of GDP) 2/

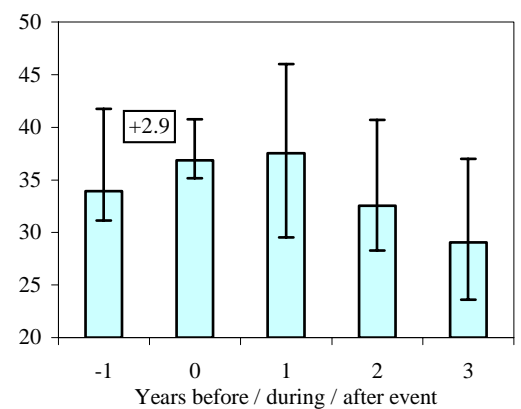

Current Account Deficit (\% of GDP)

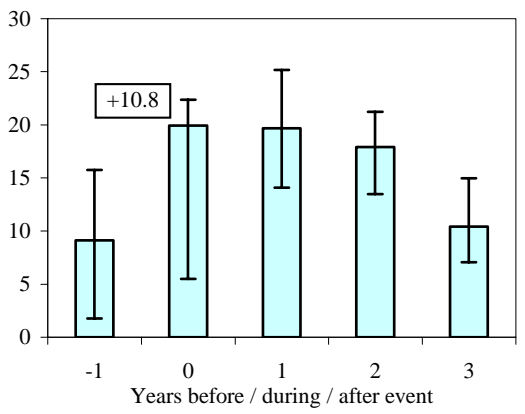

Public Investment (\% of GDP) 2/

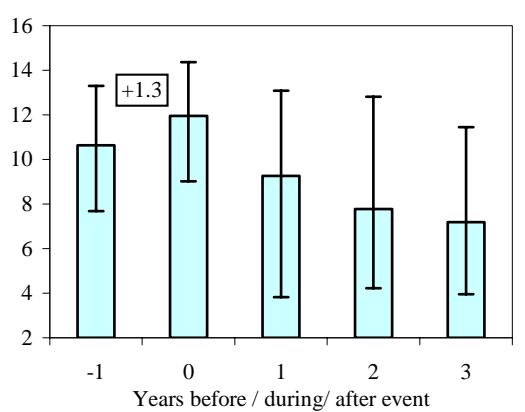

Change in Public Debt (\% of GDP) 3/

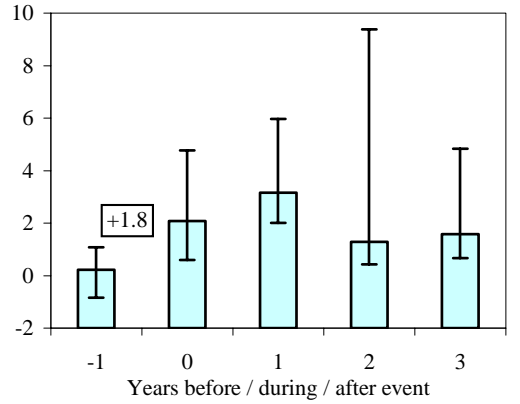

Source: IMF, World Economic Outlook database; World Bank, World Development Indicators; and Fund staff calculations.

Note: Includes the 12 natural disasters with estimated damages exceeding 2 percent of GDP shown in Table 3 (the 1987 hurricane and flood in St. Vincent and the Grenadines are treated as a single event). Bars indicate the range between the two middle quartiles of the distribution.

1/ Excludes Grenada 1975 and St. Lucia 1980.

2/ Excludes Grenada 1975 and 1980.

3/ Excludes Antigua and Barbuda 1989, Dominica 1979, and St. Lucia 1980. 
The observed deterioration in fiscal and external balances is not surprising, as governments and households would be expected to borrow in response to temporary shocks. As such, the very large impact on the current account deficit seen in the ECCU countries is a reflection of the region's high degree of openness and access to international capital. Reliance on capital markets to mitigate the impact of natural disasters also represents a source vulnerability, however, as access to financing may suddenly dry up, making it difficult to service existing debts and necessitating deep cuts in consumption.

\section{B. Long-Term Effects}

Natural disasters can affect long-term outcomes through a number of channels, including environmental damage to agriculture, fishing, and forestry (ECLAC, 2000). The destruction of schools could have a long-lasting negative impact on the stock of human capital; reconstruction efforts could crowd out productive capital expenditure; increased indebtedness could raise the rate of interest and reduce investment; and a worsening of fiscal and external balances could trigger inflation and/or financial crises. ${ }^{5}$

Evidence of the long-term economic effects of natural disasters is inconclusive. There has been little empirical analysis, and drawing firm conclusions is difficult. Among the few available studies, Benson and Clay (2003b) present findings suggesting that proneness to natural disasters has a negative impact on long-term economic growth, while the World Bank (2003) finds that natural disasters have no significant impact on growth.

Table 5 presents rank correlations between the different measures of disaster proneness and key macroeconomic indicators. The results do not point to any persistently significant correlations and some have unexpected signs. In line with the findings of Section II, the percentage of the population affected is strongly associated with low levels of income. The rank correlations also suggest that proneness to natural disasters-especially in terms of the percentage of the population affected-is associated with high volatility of income, consumption, and fiscal balances; a large agricultural sector; and a low investment-to-GDP ratio. All this is as one would expect. Contrary to what one might expect, the number of recorded events divided by land area and the percentage of the population affected are both positively correlated with GDP growth, although the relationship is not strongly significant and could be driven by other factors.

The Caribbean suffers from very high consumption volatility, which could plausibly be the result of the region's proneness to natural disasters, as suggested by the findings in Table 5. However, using cross-country regression analysis, the World Bank (2003) finds that natural disasters do not appear to be a significant determinant of consumption volatility. Also, although there is substantial variation between countries, income volatility (as measured by the standard deviation of annual real GDP growth) is not especially high in the Caribbean compared with other middle-

${ }^{5}$ IMF (2003), citing a number of different studies, finds that exogenous shocks and the associated policy responses have contributed to the accumulation of unsustainable external debt in many developing countries. 
income countries (Table 6). ${ }^{6}$ This suggests that the impact of natural disasters on aggregate volatility, if any, is small. This is perhaps not surprising given that large events are relatively rare occurrences. High consumption volatility in the Caribbean therefore probably has less to do with proneness to natural disasters than with inadequate mechanisms for consumption smoothing, in particular a relatively limited use of insurance (Auffret, 2003a, 2003b); the absence of countercyclical fiscal policy (World Bank, 2003); and generally high volatility in small states (Easterly and Kraay, 2000). Nevertheless, even if the direct impact is small, it is still possible that natural disasters have an indirect impact on aggregate volatility. For example, low levels of insurance in the Caribbean may be, in part, a result of the proneness to natural hazards impeding the efficiency of the market.

\section{Mitigating DisAsters}

This section reviews ways in which countries can reduce the cost of natural disasters and suggests that these can be substantially mitigated. Insurance and capital markets can provide compensation for loss of capital and income, alleviating the damage to household and government balance sheets, and reducing the immediate impact on consumption possibilities. Good building practices and other precautionary arrangements can lessen the impact of natural hazards in the first place. Unfortunately, these mechanisms function poorly in many of the countries most vulnerable to natural disasters, including the ECCU countries.

\section{A. Coping With Risk: The Role of Insurance and Capital Markets}

Insurance can reduce the negative impact of natural disasters by spreading the burden over space and time. The insurance market is mainly international, with local insurers reinsuring part of their exposure with larger, often global, companies. However, the market for natural hazard insurance does not operate very smoothly and is limited in scope. As described in Pollner (2001), natural disasters are "high severity, low frequency" events that are more difficult to manage for insurance companies than the "low severity, high frequency" risk that they prefer to cover. In addition, objective information on damage and risks is difficult to obtain. Consequently, the market for catastrophe risk insurance is well known to be inefficient, with high price of coverage, excessive volatility, and insufficient pooling of risk. A more efficient risk-sharing procedure would use capital markets to spread the exposure over a larger number of investors. The recent emergence of catastrophe bonds in advanced markets could help address the problem, but these are still not very widespread (Box 2).

\footnotetext{
${ }^{6}$ Cashin (2004) shows that filtering out the effect of business cycles dramatically increases the volatility of real GDP growth in the ECCU relative to that of other countries.
} 


\section{Box 2. New Instruments for Dealing with Natural Hazard Risk}

A number of capital market instruments have recently become available for weather- and disaster-related risks. Most prominent among these are catastrophe bonds, or cat bonds; other instruments include exchange-traded catastrophe options, catastrophe swaps, and weather derivatives. Cat bonds offer high yields but are subject to default if a covered catastrophe occurs during the life of the bond. Securitizing catastrophe risk in this way enables the risk to be spread more widely, thereby improving the efficiency of risk transfer.

While cat bonds and other similar instruments are still in their infancy and have so far been used only in developed countries, they could potentially help developing countries obtain large-scale protection against natural hazard risk. For example, a government could issue a cat bond to protect itself against the risk of a major hurricane. The proceeds from the bond would then be invested in risk-free securities with the spread between the two representing the recurring cost of insurance. If the specified hurricane occurs, the government would default on the cat bond and would then be free to use the funds placed in risk-free securities to cover its reconstruction costs. In order to minimize ambiguity, the bond should be tied to objective criteria such as wind speed or flood height at a specified location.

The shortcomings of the market for natural hazard insurance are especially pronounced in developing countries. In many developing countries the insurance sector is only at an early stage of development and there is very little spreading of natural hazard risk (Freeman et al., 2003). This is evident in the fact that the percentage of natural disaster damage covered by insurance is much lower than in advanced economies. According to Charvériat (2000), Latin America and the Caribbean has the lowest insurance cover of any region in the world, with only 3.9 percent of 1985-99 natural disaster damage covered by insurance-compared with 34.5 percent in North America, the region with the highest coverage.

While the ECCU insurance market is relatively advanced in comparison to that in other developing countries, coverage is not very widespread and costs are much higher than in advanced economies. Relative to the economy total property insurance premiums in the ECCU are not that much lower than in the U.S. (about 2.4 percent of GDP compared with 3.3 percent). However, this is largely a reflection of high prices, with base property insurance rates in the ECCU countries about double the rate prevailing in less hurricane-exposed cities in the United States (Pollner, 2001).

Overall, the Eastern Caribbean insurance market suffers from a high expense ratio, high fragmentation, and a low level of available risk capital. Pollner (2001) finds that the expense ratios of local insurance companies are 30-40 percent of premium income, compared with the U.S. average of 26-28 percent. With a limited domestic capital base and about 80 percent of gross property insurance premiums transferred to reinsurers, the East Caribbean insurance market is highly exposed to the volatile global reinsurance market. This has caused local insurance rates to be unduly affected by natural catastrophes in industrial countries. For example, swings in global reinsurance rates following Hurricane Andrew in Florida (1992) and the Northridge earthquake in California (1994), had a pronounced impact on property insurance rates 
in the Eastern Caribbean, with the annual cost of insurance jumping from 0.4 percent of insured value in 1990 to 1.3 percent in 1994, and declining to 0.7 percent in 1998.

Insurance coverage in the ECCU is highly uneven. The vast majority of property insurance relates to large commercial businesses, especially in the tourism sector. In contrast, even though lenders typically require mortgage holders to be insured, a large number of private dwellings are uninsured, particularly among low-income households. Public sector use of market insurance is generally limited, although some countries have recently moved toward insuring a majority of government assets. In addition, crop insurance is not always available to farmers, one exception being the WINCROP scheme.

\section{B. Domestic Public Policy to Reduce Risk and Lessen the Impact}

While many countries have taken steps to improve their preparedness for natural disasters, there appears to be scope for increasing the efficacy of policy measures. Of particular importance in the ECCU is the need to improve the functioning of the insurance market, both to increase coverage in the face of the high natural hazard risk and to reduce economic volatility. Here, government property could be insured more widely, possibly by using cat bonds or other financial innovations. Policies to encourage more widespread insurance of dwellings and crops would also be beneficial, particularly in low-income communities. Strengthening financial regulation would improve the insurance product, making it attractive to a wider segment of the economy.

In addition to promoting market-based insurance, very modest investments can often substantially reduce the structural vulnerability of infrastructure and buildings. By one estimate, investments of US\$40 billion in disaster preparedness, prevention, and mitigation would have reduced global economic losses in the 1990s by US\$280 billion (Freeman et al., 2003). For example, simple measures such as tying walls to foundation and roofs to walls may dramatically increase buildings' resistance to hurricanes (Pollner, 2001). Well-designed and strictly enforced building codes and zoning regulation are central to ensuring that construction methods are appropriate for the local environment. Implementing hurricane-resistant home improvement programs to encourage safer building practices in the informal sector, as is done in several of the ECCU countries, can also have very positive results. In other areas, governments should refrain from subsidizing monoculture, as diversification within agriculture and from agriculture to other sectors would lessen the concentration of risk.

Natural disasters cannot be entirely eliminated, especially in high risk regions such as the ECCU. Ensuring an effective response requires administrative initiatives, such as preparing emergency

\footnotetext{
${ }^{7}$ Windward Islands Crop Insurance, or WINCROP, provides storm insurance for banana growers. The scheme, which covers the entire export crop in Dominica, Grenada, St. Lucia, and St. Vincent and the Grenadines, provides cover only against a small proportion (about 20 percent) of losses, but this has proven sufficient to enable growers to rehabilitate quickly.
} 
procedures and social safety nets. It also requires financial preparedness. In principle, when market insurance is not available, risk-averse governments should each year save an amount equal to the expected cost of disasters (Freeman et al., 2003). Accumulation of contingency funds, such as those held at the Eastern Caribbean Central Bank (ECCB), would be the most obvious channel for such savings. ${ }^{8}$ For countries with very high debt levels, however, it may be more practical to use precautionary savings to pay down existing debt.

\section{International Assistance and Cooperation}

External assistance plays an important role in helping countries mitigate the effects of exogenous shocks. An increasing share of official development assistance is being devoted to emergency assistance, and multilateral financial institutions are also doing more in this area. ${ }^{9}$ Nevertheless, the very rapid increase in the frequency of natural disasters around the world suggests a need for increasing the effort. In addition, the majority of external assistance for natural disasters has been concentrated on a few very visible events, and it is possible that smaller disasters getting little media coverage are receiving too small a share of assistance. Given the small individual amounts of assistance, cooperation among agencies is important to ensure that resources are distributed appropriately.

The IMF has several instruments for providing financial assistance in response to natural disasters. The most directly targeted policy is emergency assistance for natural disaster (EAND), which has been used 27 times since 1962. Other options include the compensatory financing facility, stand-by arrangements, and PRGF arrangements. Available resources in cases of natural disaster are relatively limited, however. The total amount of financing given in the six cases where ECCU countries have accessed EAND was only US\$16 million, less than 2 percent of the estimated damage. The main benefit of EAND is that it can be provided relatively quickly (usually within two or three months after the event) with relatively little conditionality and that it can act as a catalyst for other donor flows. The compensatory financing facility may also be relevant, but is more directed at export shortfalls. Stand-By and PRGF arrangements, while permitting greater amounts of assistance, are slower to disburse, subject to conditionality, and not geared towards the problems associated with natural disasters.

Of particular relevance for the ECCU countries are the programs sponsored by the Caribbean Development Bank (CDB), the World Bank, and the Caribbean Disaster Emergency Response Agency (CDERA). The CDB, which provides assistance for disaster relief, mitigation, and

\footnotetext{
${ }^{8}$ The ECCB has a fiscal reserve account to assist member countries facing economic difficulties, including those caused by natural disasters. Contributions to the account are mandatory, with an amount automatically deducted from the profits owed to each member country, and the terms of drawings are determined on a case-by-case basis. The account, which has been in place for a decade, currently holds about EC $\$ 12$ million and has never been used in relation to a natural disaster.

${ }^{9}$ See IMF (2003) for an overview of international financing mechanisms for addressing exogenous shocks.
} 
preparedness projects, disbursed US\$50 million in loans for 27 operations during 1998-2001. The World Bank disbursed more than US\$30 million in the region during the same period, in large part for projects relating to disaster management and emergency recovery. CDERA, a regional agency established in 1991 to provide an immediate and coordinated response to disastrous events in member countries, is engaged in a wide array of disaster-management services, ranging from local information campaigns to logistical support for dispatch of relief supplies.

\section{SUMMARY OF FindiNGS}

On average, natural disasters affect about 2 percent of a country's population each year and cause damage amounting to well over one-half of 1 percent of GDP. The incidence is especially pronounced in developing countries, with the ECCU countries standing out as among the most vulnerable in the world in terms of the frequency of events. Given the high and increasing cost of disasters, there is a need for polices to better mitigate the impact of damaging natural events.

Natural disasters are typically associated with an immediate contraction in economic output, a worsening of external and fiscal balances, and an increase in poverty. The impact is clearly seen in the ECCU, where natural disasters have had pronounced macroeconomic effects.

Despite the vulnerability to natural disasters, insurance plays a limited role in developing countries. Although the insurance market is more advanced in the ECCU than in many other developing countries, property insurance is still not very widespread, especially among lowincome households. Overall, the ECCU insurance market suffers from a high expense ratio, high fragmentation, high volatility, and a small capital base.

Modest investments in preventive measures can often substantially mitigate the impact of natural hazards. Natural disasters cannot be eliminated, however, and it is important for governments to be prepared. Among other things, a tighter fiscal policy during good times would leave more room for expenditure increases in emergencies. 
Table 1. Frequency and Impact of Natural Disasters, 1970-2002 1/

\begin{tabular}{|c|c|c|c|c|c|}
\hline & 1970s & $1980 \mathrm{~s}$ & $1990 \mathrm{~s}$ & 1970-2002 & $\begin{array}{c}\text { Ratio } \\
\text { 1990s to } 1970 \mathrm{~s}\end{array}$ \\
\hline \multicolumn{6}{|l|}{ In ECCU countries (six Fund members) } \\
\hline Number of natural disasters & 6 & 18 & 18 & 44 & 3.0 \\
\hline Number of persons affected (in thousands) & 94 & 200 & 96 & 390 & 1.0 \\
\hline In percent of population 2/ & 2.08 & 3.93 & 2.53 & 2.59 & 1.2 \\
\hline Number of observations & 3 & 11 & 16 & 31 & 5.3 \\
\hline Damage (in millions of 2002 US\$) & 107 & 424 & 277 & 808 & 2.6 \\
\hline In percent of GDP 3/ & 1.90 & 2.98 & 1.70 & 2.00 & 0.9 \\
\hline Number of observations & 2 & 11 & 5 & 18 & 2.5 \\
\hline \multicolumn{6}{|c|}{ In developing countries (excluding ECCU, 120 countries) } \\
\hline Number of natural disasters & 643 & 1,296 & 1,924 & 4,952 & 3.0 \\
\hline Number of persons affected (in millions) & 723 & 1,429 & 1,886 & 5063 & 2.6 \\
\hline In percent of population 2/ & 1.50 & 2.61 & 2.31 & 2.22 & 1.5 \\
\hline Number of observations & 447 & 890 & 1531 & 3,738 & 3.4 \\
\hline Damage (in billions of 2002 US\$) & 72 & 106 & 257 & 479 & 3.6 \\
\hline In percent of GDP 3/ & 0.46 & 0.65 & 0.93 & 0.69 & 2.0 \\
\hline Number of observations & 225 & 347 & 502 & 1,276 & 2.2 \\
\hline \multicolumn{6}{|l|}{ In advanced economies (24 countries) } \\
\hline Number of natural disasters & 204 & 433 & 583 & 1,484 & 2.9 \\
\hline Number of persons affected (in millions) & 6.2 & 6.7 & 34.2 & 49.5 & 5.5 \\
\hline In percent of population 2/ & 0.08 & 0.05 & 0.52 & 0.20 & 6.3 \\
\hline Number of observations & 73 & 158 & 316 & 742 & 4.3 \\
\hline Damage (in billions of 2002 US\$) & 60 & 149 & 406 & 650 & 6.8 \\
\hline In percent of GDP 3/ & 0.06 & 0.10 & 0.08 & 0.08 & 1.4 \\
\hline Number of observations & 97 & 221 & 351 & 742 & 3.6 \\
\hline \multicolumn{6}{|l|}{ Worldwide (150 countries) } \\
\hline Number of natural disasters & 853 & 1,747 & 2,525 & 6,480 & 3.0 \\
\hline Number of persons affected (in billions) & 0.73 & 1.44 & 1.92 & 5.11 & 2.6 \\
\hline In percent of population 2/ & 1.28 & 2.24 & 1.95 & 1.88 & 1.5 \\
\hline Number of observations & 523 & 1,059 & 1,863 & 4,511 & 3.6 \\
\hline Damage (in billions of 2002 US\$) & 132 & 256 & 663 & 1,130 & 5.0 \\
\hline In percent of GDP 3/ & 0.45 & 0.65 & 0.82 & 0.64 & 1.8 \\
\hline Number of observations & 324 & 579 & 858 & 2,036 & 2.6 \\
\hline
\end{tabular}

Sources: EM-DAT; and IMF, World Economic Outlook database

1/ Omits countries without at least one natural disaster associated with a cost estimate and/or missing information on GDP.

2/ Average percentage of population affected each year. Figures are unweighted averages across countries.

3/ Average damage each year in percent of GDP. Figures are unweighted averages across countries. 
Table 2. Determinants of Vulnerability to Natural Disaster, 1970-2002

\begin{tabular}{|c|c|c|c|c|c|c|c|c|c|c|c|c|}
\hline \multirow[b]{2}{*}{ Dependent variable } & \multicolumn{9}{|c|}{$\begin{array}{lc}\text { Estimated Coefficients } \\
\end{array}$} & \multirow[b]{2}{*}{ Obs. } & \multirow[b]{2}{*}{$\mathrm{R}^{2}$} & \multirow[b]{2}{*}{ F-test } \\
\hline & Constant & $\begin{array}{c}\text { Number of Events } \\
\text { Divided by Land } \\
\text { Area }\end{array}$ & $\begin{array}{r}\text { Number of } \mathrm{E} \\
\text { Divided } \\
\text { Populati } \\
\end{array}$ & $\begin{array}{l}\text { Events } \\
\text { by } \\
\text { on }\end{array}$ & $\begin{array}{c}\text { PPP-Based } \\
\text { GDP per capita } \\
\text { (in logs) } \\
\end{array}$ & $\begin{array}{c}\text { Agriculture } \\
\text { (share in GDP) }\end{array}$ & $\begin{array}{c}\text { Investment } \\
\text { (share in GDP) }\end{array}$ & $\begin{array}{l}\text { Governme } \\
\text { Effectivene }\end{array}$ & $\begin{array}{l}\text { ent } \\
\text { ess }\end{array}$ & & & \\
\hline \multicolumn{13}{|c|}{ Affected in percent of population } \\
\hline \multirow[t]{2}{*}{ Standard OLS } & $\begin{array}{l}108.70 * * \\
(43.97)\end{array}$ & $\begin{array}{l}-5.88 \\
(4.46)\end{array}$ & $\begin{array}{l}15.25 \\
(6.88)\end{array}$ & $* *$ & $\begin{array}{l}-51.48 \text { *** } \\
(19.51)\end{array}$ & $\begin{array}{c}0.19 \\
(1.10)\end{array}$ & $\begin{array}{l}-0.23 \\
(1.57)\end{array}$ & $\begin{array}{c}26.72 \\
(14.07)\end{array}$ & & 113 & 0.25 & 5.79 \\
\hline & $\begin{array}{l}108.00 \text { *** } \\
(11.62)\end{array}$ & $\begin{array}{l}\cdots \\
\cdots\end{array}$ & $\begin{array}{c}8.42 \\
(2.61)\end{array}$ & $* * *$ & $\begin{array}{l}-49.50 * * * \\
(8.86)\end{array}$ & $\begin{array}{l}\cdots \\
\cdots\end{array}$ & $\begin{array}{l}\cdots \\
\cdots\end{array}$ & $\begin{array}{l}16.76 \\
(9.82)\end{array}$ & $*$ & 149 & 0.27 & 17.57 \\
\hline \multirow[t]{2}{*}{ Robust standard errors } & $\begin{array}{l}108.70 \text { ** } \\
(46.99)\end{array}$ & $\begin{array}{l}-5.88 \\
(4.18)\end{array}$ & $\begin{array}{l}15.25 \\
(9.27)\end{array}$ & & $\begin{array}{l}-51.48 * * \\
(21.12)\end{array}$ & $\begin{array}{c}0.19 \\
(1.14)\end{array}$ & $\begin{array}{l}-0.23 \\
(1.66)\end{array}$ & $\begin{array}{c}26.72 \\
(10.73)\end{array}$ & $* *$ & 113 & 0.25 & 4.59 \\
\hline & $\begin{array}{l}108.00 * * * \\
(15.50)\end{array}$ & $\begin{array}{l}\cdots \\
\cdots\end{array}$ & $\begin{array}{c}8.42 \\
(3.50)\end{array}$ & $* *$ & $\begin{array}{l}-49.50 * * * \\
(9.92)\end{array}$ & $\begin{array}{l}\cdots \\
\cdots\end{array}$ & $\begin{array}{l}\cdots \\
\cdots\end{array}$ & $\begin{array}{l}16.76 \\
(7.69)\end{array}$ & $* *$ & 149 & 0.27 & 15.27 \\
\hline \multicolumn{13}{|l|}{ Damage in percent of GDP } \\
\hline \multirow[t]{2}{*}{ Standard OLS } & $\begin{array}{c}10.71 \\
(15.48)\end{array}$ & $\begin{array}{l}-0.64 \\
(1.57)\end{array}$ & $\begin{array}{c}8.06 \\
(2.42)\end{array}$ & $* * *$ & $\begin{array}{l}-1.72 \\
(6.87)\end{array}$ & $\begin{array}{c}0.04 \\
(0.39)\end{array}$ & $\begin{array}{c}0.10 \\
(0.55)\end{array}$ & $\begin{array}{l}-6.68 \\
(4.95)\end{array}$ & & 113 & 0.26 & 6.18 \\
\hline & $\begin{array}{l}20.85 \text { *** } \\
(6.57)\end{array}$ & $\begin{array}{l}\cdots \\
\cdots\end{array}$ & $\begin{array}{c}8.60 \\
(1.47)\end{array}$ & $* * *$ & $\begin{array}{l}-7.46 \\
(5.01)\end{array}$ & $\begin{array}{l}\cdots \\
\cdots\end{array}$ & $\begin{array}{l}\cdots \\
\cdots\end{array}$ & $\begin{array}{l}-1.68 \\
(5.55)\end{array}$ & & 149 & 0.22 & 13.55 \\
\hline \multirow[t]{2}{*}{ Robust standard errors } & $\begin{array}{c}10.71 \\
(11.30)\end{array}$ & $\begin{array}{l}-0.64 \\
(1.87)\end{array}$ & $\begin{array}{c}8.06 \\
(3.11)\end{array}$ & $* *$ & $\begin{array}{l}-1.72 \\
(6.31)\end{array}$ & $\begin{array}{c}0.04 \\
(0.31)\end{array}$ & $\begin{array}{c}0.10 \\
(0.42)\end{array}$ & $\begin{array}{l}-6.68 \\
(4.43)\end{array}$ & & 113 & 0.26 & 4.75 \\
\hline & $\begin{array}{l}20.85 * * * \\
(6.92)\end{array}$ & $\begin{array}{l}\ldots \\
\ldots\end{array}$ & $\begin{array}{c}8.60 \\
(1.25)\end{array}$ & $* * *$ & $\begin{array}{l}-7.46 * \\
(4.40)\end{array}$ & $\begin{array}{l} \\
\ldots \\
\ldots\end{array}$ & $\begin{array}{l} \\
\ldots \\
\ldots\end{array}$ & $\begin{array}{l}-1.68 \\
(4.29)\end{array}$ & & 149 & 0.22 & 23.22 \\
\hline
\end{tabular}

Sources: EM-DAT; IMF, World Economic Outlook database; and Worldwide Governance Research Indicators Dataset

Note: Figures in parentheses are standard deviations, and "**", "**", and "***" indicate significance at, respectively, the 10, 5, and 1 percent level. The standard OLS estimations suffer from hetereoskedasticity and are therefore supplemented with hetereoskedasticity-consistent standard error estimates derived using the MacKinnon-White HC3 method. The Worldwide Governance Research Indicators Dataset captures six different dimensions of governance and assigns scores between -2.5 (worst) and +2.5 (best). The "government effectiveness" variable measures quality of public service provision and bureaucracy, the competence of civil servants, the independence of the civil service from political pressures, and the credibility of the government's commitment to policies--the numbers used here are the averages of scores for 1996-2002. The different measures of governance are highly correlated and behave similarly in the above regressions. 
Table 3. Natural Disasters in ECCU Countries, 1970-2002

\begin{tabular}{|c|c|c|c|c|c|c|}
\hline \multirow[b]{2}{*}{ Country } & \multirow[b]{2}{*}{ Year } & \multirow[b]{2}{*}{ Event } & \multicolumn{2}{|c|}{$\begin{array}{l}\text { Total persons } \\
\text { affected }\end{array}$} & \multicolumn{2}{|c|}{$\begin{array}{l}\text { Estimated } \\
\text { damage }\end{array}$} \\
\hline & & & Number & $\begin{array}{l}\text { Percent of } \\
\text { population }\end{array}$ & $\begin{array}{c}\text { US\$ } \\
\text { thousands }\end{array}$ & $\begin{array}{l}\text { Percent } \\
\text { of GDP } \\
\end{array}$ \\
\hline Antigua and Barbuda & 1983 & Drought & 75,000 & 100.0 & $\ldots$ & $\ldots$ \\
\hline Antigua and Barbuda & 1989 & Hurricane Hugo & 8,030 & 12.4 & 80,000 & 21.4 \\
\hline Antigua and Barbuda & 1990 & Hurricane Gustav & $\ldots$ & $\ldots$ & $\ldots$ & $\ldots$ \\
\hline Antigua and Barbuda & 1995 & Hurricane Luis & 68,702 & 100.0 & 500 & 0.1 \\
\hline Antigua and Barbuda & 1998 & Hurricane Georges & 2,025 & 3.0 & $\ldots$ & $\ldots$ \\
\hline Antigua and Barbuda & 1999 & Hurricane Jose & 2,534 & 3.8 & $\ldots$ & $\ldots$ \\
\hline Antigua and Barbuda & 1999 & Hurricane Lenny & 3,423 & 5.1 & $\ldots$ & $\ldots$ \\
\hline Dominica & 1970 & Hurricane & $\ldots$ & $\ldots$ & $\ldots$ & $\ldots$ \\
\hline Dominica & 1979 & Hurricanes David and Frederick & 72,100 & 100.0 & 44,650 & 100.8 \\
\hline Dominica & 1980 & Hurricane Allen & $\ldots$ & $\ldots$ & $\ldots$ & $\ldots$ \\
\hline Dominica & 1984 & Hurricane Klaus & 10,000 & 14.2 & 2,000 & 2.2 \\
\hline Dominica & 1989 & Hurricane Hugo & 710 & 1.0 & 20,000 & 13.0 \\
\hline Dominica & 1995 & Hurricane Luis & 3,001 & 4.2 & 3,428 & 1.6 \\
\hline Dominica & 1999 & Hurricane Lenny & 715 & 1.0 & $\ldots$ & $\ldots$ \\
\hline Dominica & 2001 & Hurricane Iris & 175 & 0.2 & $\ldots$ & $\ldots$ \\
\hline Grenada & 1975 & Flood & $\ldots$ & $\ldots$ & 4,700 & 13.4 \\
\hline Grenada & 1980 & Hurricane Allen & $\ldots$ & $\ldots$ & 5,300 & 7.7 \\
\hline Grenada & 1990 & Tropical storm Arthur & 1,000 & 1.1 & $\ldots$ & $\ldots$ \\
\hline Grenada & 1999 & Hurricane Lenny & 210 & 0.2 & 5,500 & 1.5 \\
\hline St. Kitts and Nevis & 1984 & Hurricane Klaus & $\ldots$ & $\ldots$ & $\ldots$ & $\ldots$ \\
\hline St. Kitts and Nevis & 1987 & Flood & $\ldots$ & $\ldots$ & 500 & 0.6 \\
\hline St. Kitts and Nevis & 1989 & Hurricane Hugo & 1,330 & 3.1 & 46,000 & 32.1 \\
\hline St. Kitts and Nevis & 1990 & Hurricane Gustav & $\ldots$ & $\ldots$ & $\ldots$ & $\ldots$ \\
\hline St. Kitts and Nevis & 1995 & Hurricane Luis & 1,800 & 4.2 & 197,000 & 85.4 \\
\hline St. Kitts and Nevis & 1998 & Hurricane Georges & 10,000 & 23.2 & ... 1/ & ... 1/ \\
\hline St. Kitts and Nevis & 1999 & Hurricane Lenny & 1,180 & 2.7 & 41,400 & 13.6 \\
\hline St. Lucia & 1980 & Hurricane Allen & 80,000 & 61.5 & 87,990 & 66.0 \\
\hline St. Lucia & 1983 & Storm & 3,000 & 2.2 & 1,290 & 0.8 \\
\hline St. Lucia & 1986 & Tropical storm Danielle & $\ldots$ & $\ldots$ & $\ldots$ & $\ldots$ \\
\hline St. Lucia & 1987 & Hurricane Emily & $\ldots$ & $\ldots$ & $\ldots$ & $\ldots$ \\
\hline St. Lucia & 1988 & Hurricane Gilbert & $\ldots$ & $\ldots$ & $\ldots 2 /$ & $\ldots 2 /$ \\
\hline St. Lucia & 1994 & Tropical storm Debby & 750 & 0.5 & $\ldots$ & $\ldots$ \\
\hline St. Lucia & 1996 & Landslide & 175 & 0.1 & $\ldots$ & $\ldots$ \\
\hline St. Lucia & 1999 & Hurricane Lenny & 200 & 0.1 & $\ldots$ & $\ldots$ \\
\hline St. Vincent and the Grenadines & 1971 & Volcano & 2,000 & 2.3 & $\ldots$ & $\ldots$ \\
\hline St. Vincent and the Grenadines & 1977 & Flood & $\ldots$ & $\ldots$ & $\ldots$ & $\ldots$ \\
\hline St. Vincent and the Grenadines & 1979 & Volcano & 20,000 & 18.6 & $\ldots$ & $\ldots$ \\
\hline St. Vincent and the Grenadines & 1980 & Hurricane Allen & 20,500 & 18.8 & 16,300 & 27.6 \\
\hline St. Vincent and the Grenadines & 1986 & Flood & 152 & 0.1 & $\ldots$ & $\ldots$ \\
\hline St. Vincent and the Grenadines & 1987 & Hurricane Emily & 208 & 0.2 & 5,300 & 3.7 \\
\hline St. Vincent and the Grenadines & 1987 & Flood & 1,000 & 0.9 & 5,000 & 3.5 \\
\hline St. Vincent and the Grenadines & 1992 & Flood & 200 & 0.2 & $\ldots$ & $\ldots$ \\
\hline St. Vincent and the Grenadines & 1999 & Hurricane Lenny & 100 & 0.1 & $\ldots$ & $\ldots$ \\
\hline St. Vincent and the Grenadines & 2002 & Hurricane Lili & $\ldots$ & $\ldots$ & $\ldots$ & $\ldots$ \\
\hline
\end{tabular}

Sources: EM-DAT; and IMF, World Economic Outlook database.

1/ St. Kitts National Emergency Management Agency estimated damage of US\$402 million (140 percent of GDP).

2/ EM-DAT's entry for damage (US\$1 billion, or 305 percent of GDP) is omitted, as it was disputed by national authorities. 
Table 4. Worldwide Incidence of Natural Disasters, 1970-2002

\begin{tabular}{|c|c|c|c|c|c|c|c|c|c|c|c|}
\hline & \multicolumn{5}{|c|}{ All Recorded Disasters } & \multicolumn{3}{|c|}{$\begin{array}{l}\text { With Estimates of } \\
\text { Persons Affected }\end{array}$} & \multicolumn{3}{|c|}{ With Estimates of Damage } \\
\hline & \multirow{2}{*}{$\begin{array}{l}\text { Number } \\
\text { of Events }\end{array}$} & \multicolumn{2}{|c|}{$\begin{array}{c}\text { Number of Events } \\
\text { Divided by } \\
\text { Land Area }\end{array}$} & \multicolumn{2}{|c|}{$\begin{array}{c}\text { Number of Events } \\
\text { Divided by } \\
\text { Population }\end{array}$} & \multirow{2}{*}{$\begin{array}{l}\text { Number } \\
\text { of Events }\end{array}$} & \multicolumn{2}{|c|}{$\begin{array}{c}\text { Cumulative } \\
\text { Affected in Percent } \\
\text { of Population }\end{array}$} & \multirow{2}{*}{$\begin{array}{l}\text { Number } \\
\text { of Events }\end{array}$} & \multicolumn{2}{|c|}{$\begin{array}{c}\text { Cumulative } \\
\text { Damage in Percent } \\
\text { of Annual GDP }\end{array}$} \\
\hline & & Index & Rank & Index & Rank & & Total & Rank & & Total & Rank \\
\hline All countries & 6,480 & 100 & 76 & 100 & 76 & 4,511 & 62 & 76 & 2,036 & 21 & 76 \\
\hline Advanced economies & 1,511 & 23 & 70 & 39 & 91 & 742 & 7 & 119 & 742 & 3 & 104 \\
\hline Caribbean & 162 & 599 & 23 & 387 & 23 & 114 & 65 & 66 & 58 & 37 & 46 \\
\hline ECCU6 & 44 & 1,212 & 5 & 770 & 6 & 31 & 85 & 58 & 18 & 66 & 19 \\
\hline Antigua and Barbuda & 7 & 1,198 & 3 & 883 & 4 & 6 & 248 & 7 & 2 & 22 & 34 \\
\hline Dominica & 8 & 803 & 8 & 890 & 3 & 6 & 125 & 27 & 4 & 118 & 7 \\
\hline Grenada & 4 & 886 & 7 & 348 & 12 & 2 & 1 & 127 & 3 & 23 & 32 \\
\hline St. Kitts and Nevis 1/ & 7 & 1,465 & 2 & 1,295 & 2 & 4 & 33 & 70 & 4 & 132 & 6 \\
\hline St. Lucia 2/ & 8 & 988 & 6 & 451 & 8 & 5 & 64 & 52 & 2 & 67 & 13 \\
\hline St. Vincent and Grenadines & 10 & 1,931 & 1 & 755 & 6 & 8 & 41 & 67 & 3 & 35 & 23 \\
\hline Other Caribbean & 118 & 190 & 36 & 131 & 35 & 83 & 52 & 71 & 40 & 17 & 63 \\
\hline Bahamas & 5 & 38 & 37 & 170 & 20 & 2 & 1 & 128 & 2 & 13 & 49 \\
\hline Barbados & 6 & 1,051 & 4 & 193 & 19 & 5 & 3 & 117 & 3 & 7 & 67 \\
\hline Belize & 10 & 33 & 41 & 457 & 7 & 7 & 131 & 25 & 7 & 51 & 16 \\
\hline Dominican Republic & 23 & 36 & 39 & 29 & 69 & 14 & 62 & 53 & 4 & 17 & 40 \\
\hline Guyana & 6 & 2 & 128 & 67 & 39 & 3 & 89 & 42 & 2 & 4 & 77 \\
\hline Haiti & 36 & 98 & 23 & 47 & 50 & 30 & 83 & 46 & 4 & 9 & 62 \\
\hline Jamaica & 23 & 160 & 17 & 82 & 33 & 15 & 74 & 49 & 13 & 50 & 17 \\
\hline Netherlands Antilles & 2 & 188 & 14 & 90 & 31 & 1 & 20 & 78 & 1 & 1 & 122 \\
\hline Trinidad and Tobago & 7 & 103 & 21 & 48 & 47 & 6 & 5 & 104 & 4 & 1 & 119 \\
\hline Other & 4,807 & 49 & 84 & 75 & 79 & 3,655 & 74 & 67 & 1,236 & 23 & 73 \\
\hline GDP per capita of top-20 3/ & $\ldots$ & $\ldots$ & 4.2 & $\ldots$ & 5.5 & $\ldots$ & $\ldots$ & 1.4 & $\ldots$ & $\ldots$ & 1.9 \\
\hline
\end{tabular}

Sources: EM-DAT for data on natural disasters, including estimates of the number of people affected and the value of damage; World Bank, World Development Indicators for data on land area; IMF, World Economic Outlook database for data on GDP and population.

Note: The sample contains 150 countries after omitting countries without at least one natural disaster associated with a cost estimate and/or missing information on GDP (24 advanced economies, 15 Caribbean countries, and 111 other developing countries). Simple unweighted averages are used for country groupings. Rankings are in descending order, with "1" indicating the most exposed to natural disaster.

1/ Using St. Kitts National Emergency Management Agency's damage estimate for 1998 Hurricane Georges would have implied a ranking of "2" in the last column.

2/ Excludes EM-DATs damage estimate for 1988 Hurricane Gilbert. If included this would have implied a ranking of "1" in the last column.

3/ In thousands of US\$ in 2002. 
Table 5. Correlations Between Measures of Proneness to Natural Disasters and Selected Macroeconomic Variables, 1970-2002

\begin{tabular}{|c|c|c|c|c|c|c|c|c|c|c|c|c|}
\hline & freq1 & freq2 & affect & damage & lpppc & lgdpc & grgdp & vrgdp & vcons & vgovbp & agri & tiratio \\
\hline \multicolumn{13}{|c|}{ Number of events divided by country area } \\
\hline Number of obs & 150 & 150 & 150 & 150 & 150 & 149 & 149 & 149 & 120 & 140 & 137 & 117 \\
\hline Correlation & $\ldots$ & 0.67 & 0.08 & 0.23 & -0.06 & -0.07 & 0.20 & -0.05 & 0.19 & 0.07 & -0.10 & -0.10 \\
\hline Spearman's rho & $\ldots$ & 0.57 & 0.20 & 0.28 & 0.05 & 0.07 & 0.16 & -0.11 & 0.09 & -0.05 & 0.01 & 0.01 \\
\hline P-value & $\ldots$ & $\mathbf{0 . 0 0}$ & 0.01 & 0.00 & 0.55 & 0.40 & 0.05 & 0.17 & 0.35 & 0.58 & 0.91 & 0.93 \\
\hline \multicolumn{13}{|c|}{ Number of events divided by country population } \\
\hline Number of obs & 150 & 150 & 150 & 150 & 150 & 149 & 149 & 149 & 120 & 140 & 137 & 117 \\
\hline Correlation & 0.67 & $\ldots$ & 0.22 & 0.43 & -0.09 & -0.08 & 0.12 & -0.04 & 0.18 & 0.06 & -0.06 & -0.07 \\
\hline Spearman's rho & 0.57 & $\ldots$ & 0.46 & 0.35 & -0.15 & -0.14 & 0.12 & 0.04 & 0.31 & 0.22 & 0.12 & -0.22 \\
\hline P-value & $\mathbf{0 . 0 0}$ & $\ldots$ & 0.00 & 0.00 & 0.07 & 0.09 & 0.15 & 0.60 & 0.00 & 0.01 & 0.16 & 0.02 \\
\hline \multicolumn{13}{|c|}{ Persons affected (in percent of population) } \\
\hline Number of obs & 150 & 150 & 150 & 150 & 150 & 149 & 149 & 149 & 120 & 140 & 137 & 117 \\
\hline Correlation & 0.08 & 0.22 & $\ldots$ & 0.26 & -0.40 & -0.35 & 0.20 & 0.04 & 0.29 & 0.15 & 0.36 & -0.34 \\
\hline Spearman's rho & 0.20 & 0.46 & $\ldots$ & 0.54 & -0.61 & -0.62 & 0.19 & 0.17 & 0.43 & 0.07 & 0.53 & -0.47 \\
\hline P-value & 0.01 & $\mathbf{0 . 0 0}$ & $\ldots$ & 0.00 & $\mathbf{0 . 0 0}$ & 0.00 & 0.02 & 0.03 & 0.00 & 0.43 & 0.00 & $\mathbf{0 . 0 0}$ \\
\hline \multicolumn{13}{|c|}{ Damage (in percent of GDP) } \\
\hline Number of obs & 150 & 150 & 150 & 150 & 150 & 149 & 149 & 149 & 120 & 140 & 137 & 117 \\
\hline Correlation & 0.23 & 0.43 & 0.26 & $\ldots$ & -0.23 & -0.20 & -0.04 & 0.08 & 0.11 & 0.08 & 0.13 & -0.18 \\
\hline Spearman's rho & 0.28 & 0.35 & 0.54 & $\ldots$ & -0.28 & -0.26 & 0.13 & 0.05 & 0.14 & -0.02 & 0.25 & -0.15 \\
\hline P-value & $\mathbf{0 . 0 0}$ & 0.00 & 0.00 & $\ldots$ & 0.00 & 0.00 & 0.12 & 0.52 & 0.13 & 0.85 & 0.00 & 0.10 \\
\hline
\end{tabular}

Sources: IMF, International Financial Statistics, and World Economic Outlook database; and World Bank, World Development Indicators.

Note: Bolded figures indicate that the rank correlations are significant at the 5 percent level (one-sided test). A positive correlation suggests that higher values of the variable are associated with an increased proneness to natural disaster, as reflected by the four measures in the first column.

Variables: freq1, number of events divided by country land area; freq2, number of events divided by country population; affect, percentage of population affected; damage, damage in percent of annual GDP; lpppc, average level of current price GDP per capita at PPP exchange rate; lgdpc, average level of current price GDP in USD per capita; grgdp, average growth rate of constant price GDP; vrgdp, standard deviation of constant price GDP; vcons, standard deviation of total consumption in US dollars; vgovbp, standard deviation of central government balance in percent of GDP; agri, share of agriculture in GDP; tiratio, average ratio of total investment to GDP. 
Table 6. Volatility of Income and Consumption, 1970-2002 (Standard deviation of annual growth rates, in percent)

\begin{tabular}{lrrr}
\hline & & \multicolumn{2}{c}{ Consumption } \\
\cline { 3 - 4 } & GDP & Households & Government \\
\hline ECCU6 (average) & 4.5 & 11.0 & 9.9 \\
Antigua and Barbuda & 3.2 & 13.3 & 7.9 \\
Dominica & 5.8 & 6.9 & 8.9 \\
Grenada & 3.6 & 8.3 & 11.2 \\
St. Kitts and Nevis & 3.2 & 11.1 & 8.8 \\
St. Lucia & 7.6 & 13.4 & 10.0 \\
St. Vincent and the Grenadines & 3.5 & 12.7 & 12.4 \\
Low-income countries & 6.1 & 10.7 & 16.2 \\
Middle-income countries & 6.0 & 8.2 & 9.5 \\
High-income countries & 3.3 & 2.9 & 2.4 \\
\hline
\end{tabular}

Source: World Bank, World Development Indicators; ECCU Country Authorities; and IMF staff estimates.

Note: Underlying data in constant 1995 US dollars. 


\section{REFERENCES}

Atkins, J.P., S. Mazzi, and C.D. Easter, 2000, “A Commonwealth Vulnerability Index for Developing Countries: The Position of Small States,” Economic Paper No. 40 (London: Commonwealth Secretariat).

Auffret, P., 2003a, “High Consumption Volatility: the Impact of Natural Disasters,” World Bank Working Paper No. 2962 (Washington: World Bank).

_ 2003b, “Catastrophe Insurance Market in the Caribbean Region: Market Failures and Recommendations for Public Sector Interventions,” Policy Research Working Paper No. 2963 (Washington: World Bank).

Benson, C. and E. Clay, 2003a, Economic and Financial Impacts of Natural Disasters: an Assessment of Their Effects and Options for Mitigation (London: Overseas Development Institute).

— , 2003b, “Disasters, Vulnerability and the Global Economy,” in A. Kreimer, M. Arnold, and A. Carlin (Eds.), Building Safer Cities: The Future of Disaster Risk (Washington: World Bank).

— F.V. Michael, and A.W. Robertson, 2001, “Dominica: Natural Disasters and Economic Development in a Small Island State,” Disaster Risk Management Working Paper Series No. 2 (Washington: World Bank).

Caselli, F. and P. Malhotra, 2004, "Natural Disasters and Growth: from Thought Experiment to Natural Experiment,” Unpublished Draft, International Monetary Fund.

Cashin, P., 2004, “Key Features of Caribbean Business Cycles,” IMF Working Paper WP/04/136 (Washington: International Monetary Fund).

Charvériat, C., 2000, "Natural Disasters in Latin America and the Caribbean: An Overview of Risk,” Working Paper No. 434 (Washington: Inter-American Development Bank).

Collier, P., and J. Dehn, 2001, “Aid, Shocks, and Growth,” World Bank Working Paper No. 2688 (Washington: World Bank).

Crowards, T., 2000a, “An Index of Inherent Economic Vulnerability of Developing Countries,” Staff Working Paper No. 6/00 (St. Michael, Barbados: Caribbean Development Bank).

_ 2000b, “Comparative Vulnerability to Natural Disasters in the Caribbean,” Staff Working Paper No. 1/00 (St. Michael, Barbados: Caribbean Development Bank).

Crowards, T., and W. Coulter, 1998, "Measuring The Comparative Vulnerability of the Eastern Caribbean,” Working Paper (St. Michael, Barbados: Caribbean Development Bank).

Centre for Research on the Epidemiology of Disasters (CRED), 2004, “EM-DAT: The OFA/CRED International Disaster Database,” http://www.em-dat.net/.

Easterly, W., and A. Kraay, 2000, "Small States, Small Problems? Income, Growth, and Volatility in Small States,” World Development, Vol. 28, pp. 2013-2027. 
Economic Commission for Latin America and the Inter-American Development Bank (ECLAC), 2000, "A Matter of Development: How to Reduce Vulnerability in the Face of Natural Disasters" (Port-of-Spain, Trinidad and Tobago).

Freeman, P.K., M. Keen, and M. Mani, 2003, "Dealing with Increased Risk of Natural Disasters: Challenges and Options,” IMF Working Paper WP/03/197 (Washington: International Monetary Fund).

Intergovernmental Panel on Climate Change, 2001, “Third Assessment Report - Climate Change 2001” (Geneva, Switzerland).

International Monetary Fund, 2003, "Fund Assistance for Countries Facing Exogenous Shocks," http://www.imf.org/external/np/pdr/sustain/2003/080803.pdf.

Pollner, J., 2001, "Managing Catastrophic Disaster Risk Using Alternative Risk Financing and Pooled Insurance Systems,” World Bank Technical Paper No. 495 (Washington: World Bank).

United Nations, 2000, “Committee for Development Policy’s Economic Vulnerability Index: Explanatory Note," http://www.un.org/esa/policy/devplan/cdp00p21.pdf

World Bank, 2003, "Caribbean Economic Overview 2002: Macroeconomic Volatility, Household Vulnerability, and Institutional and Policy Responses," Report No. 24165LAC (Washington: World Bank). 